\title{
Penentuan Paket Promosi Pakaian PT. D\&C Production dengan Menggunakan Algoritma FP-Growth
}

\author{
Muhammad Rizky*1, Azhari Ali Ridha ${ }^{2}$, Kamal Prihandani ${ }^{3}$ \\ ${ }^{1,2,3}$ Progam Studi Teknik Informatika, Universitas Singaperbangsa Karawang \\ muhammad.rizky17152@student.unsika.ac.id*1, azhari.ali@unsika.ac.id ${ }^{2}$, \\ kamal.prihandani@unsika.ac.id ${ }^{3}$
}

(Received: 25 Juni 2021/ Accepted: 2 Juli 2021/ Published Online: 20 Desember 2021)

\begin{abstract}
Abstrak
PT. D\&C Production merupakan pusat penjualan kasur rusfur, kasur busa, kasur matras dengan segala ukuran dan model, berbagai jenis aksesoris mobil dan berbagai macam pakaian dalam wanita dan pria. Permasalahan mengenai penurunan penjualan mengakibatkan juga penumpukan barang sehingga menjadi kerugian. Penelitian ini bertujuan menerapkan algoritma fp-growth untuk membantu perusahaan meningkatkan penjualannya dengan membuat paket promosi pakaian dalam. Adapun dataset yang digunakan untuk mendukung penelitian ini adalah dataset transaksi penjualan periode bulan April 2020 hingga Desember 2020. Hasil penelitian menunjukkan bahwa telah didapatkan aturanaturan yang diketahui dengan menggunakan algoritma fp-growth, dimana aturan asosiasi ini dapat membuat strategi untuk meningkatkan penjulan pakaian berupa 5 aturan asosiasi yang siap dijadikan untuk pembuatan paket promosi pakaian dengan memenuhi nilai support dan nilai confidence yang telah ditetapkan diawal yaitu memiliki nilai confidence diatas $80 \%$ dan nilai support diatas $25 \%$
\end{abstract}

Kata kunci: Association Rule, FP-Growth, Data Mining, RapidMiner, Paket Promosi

\section{Abstract}

PT. D\&C Production is a center for selling rusfur mattresses, foam mattresses, mattress mattresses of all sizes and models, various types of car accessories and a wide variety of women's and men's underwear. Problems regarding declining sales resulted in also the accumulation of goods so that it became a loss. The research aims to implement fp-growth algorithms to help companies increase their sales by creating underwear promotion packages. The dataset used to support this research is a sales transaction dataset from April 2020 to December 2020. The results showed that there have been known rules using the fp-growth algorithm, where the rules of this association can create strategies to improve the sales of clothing in the form of 5 association rules that are ready to be used for the manufacture of clothing promotion packages by meeting the support value and confidence values that have been set at the beginning, namely having a confidence value. above $80 \%$ and support value above $25 \%$.

Keywords: Association Rule, FP-Growth, Data Mining, Rapid Miner, Promotion Bundle

\section{PENDAHULUAN}

Perusahaan D\&C Production menjual kasur rusfur dengan kualitas yang sangat baik. Selain kasur, perusahaan ini juga menjual berbagai jenis karpet, model pakaian dalam wanita, serta berbagai macam aksesoris mobil. Selama berjalannya perusahaan ini, penjualan yang tercatat tidak selalu stabil pada penjualan pakaian dalam bagian bawah wanita. Gambar 1 adalah penurunan penjualan pada produk tersebut mulai dari bulan Juli hingga Desember di tahun 2020. 


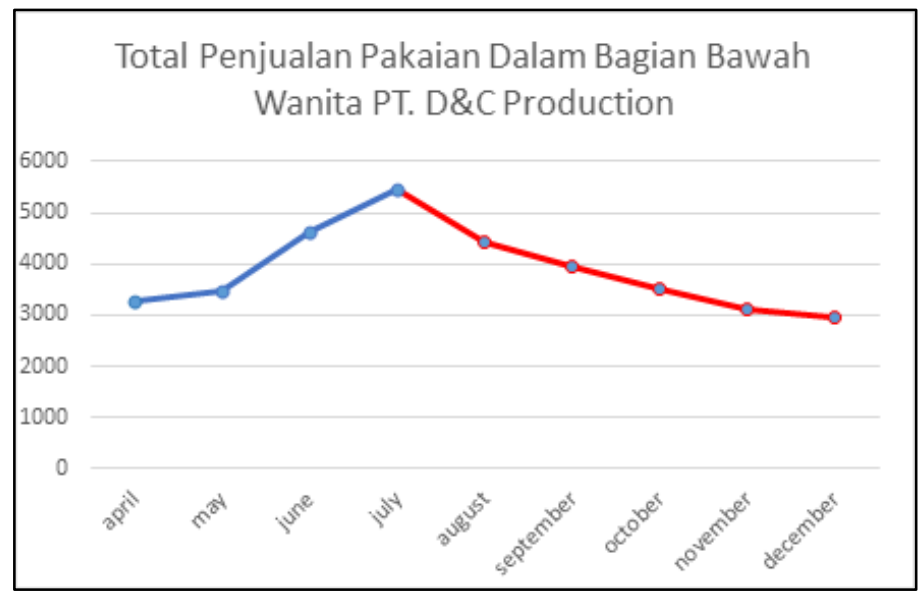

Gambar 1. Data Penjualan Perbulan (April-Desember 2020)

Untuk mengurangi resiko penurunan penjualan, dapat dilakukan pemasaran produk dengan membuat sebuah paket promosi pakaian. Permasalahan tersebut dapat dipecahkan dengan bantuan data mining dengan membuat model pengetahuan berbasis data penjualan produk sebagai bahannya (Syahra, 2019). Data mining merupakan proses pencarian pola ataupun data unik dari informasi terpilih menggunakan memakai metode ataupun tata cara tertentu. Salah satu proses pencarian pola yang ada pada data mining yaitu asosiasi (Mardi, 2017). Dengan asosiasi, dataset yang ada dapat dimanfaatkan untuk membantu membuat promosi dilihat dari pola pembelian pelanggan yang akan menghasilkan sebuah frequent itemset (Syahra, 2019).

Saat melakukan asosiasi, dua algoritma yang dapat digunakan diantaranya apriori dan fp-growth. Maulidiya \& Jananto (2020) menggunakan algoritma fp-growth dengan alasan algoritma ini menghasilkan rule dan kombinasi item yang lebih banyak dengan akurasi yang lebih baik dari apriori. Algoritma fp-growth adalah sebuah pengembangan dari algoritma apriori dengan cara pencarian frequent itemset pada data mining tanpa menggunakan candidate generation (Maulana \& Fajrin, 2018). Pada aturan asosiasi memiliki dua buah parameter yang menjadi patokan untuk perhitungan nantinya yaitu support dan confidence. Nilai support adalah nilai penunjang yang berupa presentase dari item-item yang ada pada database. Nilai confidence adalah nilai akurasi pada item-item yang ada pada aturan asosiasi (Fajrin, Puspitasari, \& Ikawati, 2020).

Beberapa penelitian telah dilakukan dengan algoritma fp-growth. Pada penelitian sebelumnya, Takdirillah (2020) melakukan penelitian tentang penerapan data mining dengan algoritma apriori sebagai pendukung informasi strategi penjualan dengan menghasilkan berupa aturan asosiasi sebanyak 3 aturan dengan 2 kombinasi item yang digunakan menjadi informasi strategi penjualan. Penelitian lain menggunakan algoritma fp-growth untuk membuat sebuah paket promosi berdasarkan data penjualannya dan menyimpulkan bahwa algoritma $f p$ growth mempermudah pengguna dalam mencari barang yang layak dijadikan paket promosi dan menghasilkan 4 aturan asosiasi dengan beberapa kombinasi item yang dapat dijadikan sebuah acuan pertimbangan apabila ingin melakukan bundling item atau sebuah paket promosi (Setiawan \& Anugrah, 2019). Penelitian lain juga dilakukan oleh Abdullah (2018) yang membuat rekomendasi paket produk untuk meningkatkan penjualan dengan menggunakan $f p$ growth menemukan bahwa ada dua pasang barang dengan nilai support dan confidence yang memenuhi syarat nilai minimum.

Berdasarkan hal tersebut, penelitian ini bertujuan menerapkan algoritma fp-growth untuk membentuk sebuah model asosiasi, sehingga perusahaan meningkatkan penjualannya dengan membuat paket promosi pakaian dalam. Adapun dataset yang akan digunakan untuk mendukung penelitian ini adalah dataset transaksi penjualan periode bulan April 2020 hingga 
Desember 2020, yang akan diproses menggunakan perhitungan manual serta bantuan tool RapidMiner.

\section{METODE}

Penelitian ini menggunakan data dari perusahaan yang berupa nota penjualan lalu dilakukan memasukan data dalam bentuk excel. Data yang digunakan merupakan data penjualan pakaian periode bulan april hingga desember 2020 sebanyak 86 nota. Penelitian ini dilakukan berdasarkan pada metode Knowledge Discovery Database (KDD) alur penelitian yang akan dilaksanakan terdiri dari 5 tahap (Chandra, 2017).

Pada tahap pertama adalah data selection. Tahap ini merupakan proses pemilihan data yang akan dijadikan sebagai target/atribut/indicator. Lalu tahap kedua adalah pre processing. Pre processing/cleaning. Tahap ini dilakukannya penghapusan data yang tidak relevan dan data yang tidak konsisten guna untuk menghindari adanya redudasi data dan juga untuk memudahkan pada tahap integrasi data. Tahap ketiga adalah transformasi data. Transformasi data (Data Transformation) merupakan proses perubahan data yang bertujuan untuk mempermudah proses data mining selanjutnya. Pada penelitian ini data akan diubah kedalam bentuk data tabular.

Tahap selanjutnya adalah tahap data mining. Algoritma yang digunakan pada peneltian ini menggunakan algoritma fp-growth. Tahapan-tahapan FP-Growth memiliki tugas tahapan (Pranata \& Utomo, 2020). Tahap yang pertama adalah pembangkitkan conditional pattern base. Lalu tahap yang kedua adalah pembangkitkan conditional FP-Tree. Lalu tahap yang terakhir adalah pencarian frequent itemset.

Di dalam fp-growth terdapat frequent itemset. Frequent itemset adalah semua itemset yang ada pada database yang memiliki nilai minimum support yang ditentukan oleh penggunanya (Prahartiwi, 2017). Nilai support akan digunakan untuk mencari seberapa banyak aturan yang diterapkan pada dataset. Berikut merupakan rumus pada persaman 1 dan 2 untuk perhitungan nilai support untuk satu item dan untuk dua item.

$$
\begin{aligned}
& \text { Support }(\mathrm{A})=\frac{\text { Jumlah } \text { Transaksi } A}{\text { Total } \text { Transaksi }} \\
& \text { Support }(\mathrm{A})=\frac{\text { Jumlah } \text { Transaksi Adan B }}{\text { Total } \text { Transaksi }}
\end{aligned}
$$

Setelah frequent itemset ditemukan, selanjutnya adalah melakukan pencarian aturan asosiasi yang memenuhi nilai confidence. Berikut merupakan rumus untuk perhitungan nilai confidence pada persamaan 3

$$
\text { Confidence }(\mathrm{A} \mid \mathrm{B})=\frac{\text { Jumlah } \operatorname{Transaksi} A \text { dan } B}{\text { Jumlah } \operatorname{Transaksi} A}
$$

Pada penelitian ini juga melakukan pengolahan data dengan menggunakan aplikasi RapidMiner. Rapid miner adalah sebuah tool yang digunakan untuk mengolah data yang telah didapatkan dengan menggunakan metode data mining dan menganalisis kuantitas data secara kualitatif (Pamulang, Aini, \& Enri, 2021; Sari, Firdausi, \& Azhar, 2020). Rapid miner ini merupakan sebuah tools open source atau tool yang gratis. Rapid miner ini dapat menghasilkan grafik yang diiginkan. Dari grafik itulah kita dengan mudah mendapatkan sebuah kesimpulan (Rahmat C.T.I. et al., 2017; Uska, Wirasasmita, Usuluddin, \& Arianti, 2020).

Tahap terkhir adalah evaluasi. Evaluasi Pola (Pattern Evaluation atau Interpretation) merupakan proses menampilkan pola/visualisasi dari hasil data mining yang telah dilakukan dan melakukan pengidentifikasian pola-pola menarik. Pada tahap ini juga melakukan evaluasi terhadap frequent itemset yang telah didapat dengan menggunakan lift ratio untuk mengukur 
aturan yang telah terbentuk seberapa pentingnya aturan tersebut (Fitria, Nengsih, \& Qudsi, 2017). Berikut merupakan rumus untuk perhitungan lift ratio yang tertera pada persamaan 4.

$$
\text { Lift Ratio }(\mathrm{A} \rightarrow \mathrm{B})=\frac{\text { Confidence }(A \rightarrow B)}{\operatorname{Support}(B)}
$$

\section{HASIL DAN PEMBAHASAN}

Hasil

\section{Data Selection}

Pada penelitian ini dilakukan seleksi data dengan menyeleksi dan memfokuskan pada subset atau atribut, karena akan dilakukan pengambilan beberapa atribut yang relevan untuk memudahkan dalam proses data mining. Attribut akan diseleksi dari 7 atribut menjadi 2 atribut saja yaitu atribut kode niota dan nama barang seperti pada tabel 1 .

Tabel 1. Hasil Seleksi Data

\begin{tabular}{ccc}
\hline Atribut & Tipe Data & Keterangan \\
\hline Kode Nota & Nominal & Merupakan kode pada setiap nota pembelian barang. \\
Nama Barang & Nominal & Merupakan nama barang yang dibeli. \\
\hline
\end{tabular}

\section{Pre Processing}

Pada tahapan ini dilakukannya tahap pre-processing pada data yang telah diolah sebelumnya pada tahap data selection. Pada tahap ini akan dilakukannya pencarian missing value pada data yang telah diseleksi sebelumnya, namun pada dataset yang digunakan tidak ada tersedeksi attribute yang memiliki missing value maka dilanjutkan pada proses selanjutnya. Seluanjutnya adalah melaukan pencarian inkonsistensi berupa redudansi data dan melakukan penghapusan pada data tersebut. Terdapat redudansi data atau data berulang pada dataset yang digunakan maka data tersebut harus dihilangkan hingga menyisakan hannya satu data saja. Setelah proses pre processing dilakukan, jumlah data yang tersisa pada dataset sebanyak 302 record data. Data yang telah diproses ini akan dilanjutkan ketahap selanjutnya yaitu data transformation.

\section{Transformation}

Pada proses Data Transformation akan melakukan proses perubahan data yang bertujuan untuk mempermudah pengolahan dan analisis data yang digunakan. Pada proses ini melakukan pengubahan menjadi format tabular data. Dimana atribut kode nota akan menjadi tipe data id dan nama nama barang menjadi tipe data binomial. Pada tabel 2 merupakan data yang belum dilakukan data transformasi dalam bentuk format tabular data.

Atribut nama barang terdiri dari cd, cd xxl, cd jupe, cd jupe xxl, short, short xxl. Angka 1 artinya ada transaksi dan angka 0 itu idak ada transaksi. Berikut merupakan contoh data yang sudah dilakukannya proses data tabular pada dataset seperti pada tabel 3. Setelah dilakukannya proses tabular data merubah nilai nilai atribut serta susunan format tabular data sudah siap digunakan untuk proses data mining dengan teknik algoritma fp-growth.

Tabel 2. Data Sebelum Data Transformation

\begin{tabular}{cc}
\hline Kode Nota & Nama Barang \\
\hline nt001 & short xxl \\
nt001 & short \\
$\ldots$ & $\ldots$ \\
nt086 & cd \\
\hline
\end{tabular}


Tabel 3. Data Setelah Proses Tabular Data

\begin{tabular}{cccccccc}
\hline Kode Nota & cd & cd xxl & cd jupe & cd jupe xxl & short & short xxl & cd 4xl \\
\hline nt001 & 1 & 1 & 1 & 1 & 1 & 1 & 1 \\
nt002 & 1 & 1 & 0 & 1 & 1 & 1 & 0 \\
nt003 & 1 & 1 & 1 & 0 & 1 & 1 & 0 \\
$\ldots$ & $\ldots$ & $\ldots$ & $\ldots$ & $\ldots$ & $\ldots$ & $\ldots$ & $\ldots$ \\
nt086 & 1 & 1 & 1 & 0 & 0 & 0 & 0 \\
\hline
\end{tabular}

\section{Data Mining}

Langkah pertama dalam proses data mining ini adalah menentukan item mana yang akan digunakan dalam perhitungan manual dengan cara menghitung nilai minimum support count per item yang dimana nantinya item yang memiliki nilai support dibawah batas minimum akan dihapuskan atau tidak digunakan seperti pada tabel 4. Pada penelitian ini menetapkan bahwa minimum support yang digunakan adalah $25 \%$.

Tabel 4. Minimum Support per Item

\begin{tabular}{cccc}
\hline No & Nama Barang & Frekuensi & Support \\
\hline $\mathbf{1}$ & cd & 63 & $73,26 \%$ \\
$\mathbf{2}$ & cd xxl & 47 & $54,65 \%$ \\
$\mathbf{3}$ & cd jupe & 38 & $44,19 \%$ \\
$\mathbf{4}$ & cd jupe xxl & 30 & $34,88 \%$ \\
$\mathbf{5}$ & short & 51 & $59,30 \%$ \\
$\mathbf{6}$ & short xxl & 53 & $61,63 \%$
\end{tabular}

Total transaksi $\quad 81$

Tabel 5. Data Setelah Penghapusan Itemset yang Tidak Memenuhi Min.Support

\begin{tabular}{ccccccc}
\hline Kode Nota & cd & cd xxl & cd jupe & cd jupe xxl & short & short xxl \\
\hline nt001 & 1 & 1 & 1 & 1 & 1 & 1 \\
nt002 & 1 & 1 & 0 & 1 & 1 & 1 \\
nt003 & 1 & 1 & 1 & 0 & 1 & 1 \\
$\ldots$ & $\ldots$ & $\ldots$ & $\ldots$ & $\ldots$ & $\ldots$ & $\ldots$ \\
nt086 & 1 & 1 & 1 & 0 & 0 & 0 \\
\hline
\end{tabular}

Setelah mendapatkan nilai support count per itemnya, item yang tidak memenuhi nilai minimum support akan di hilangkan atau tidak digunakan, pada penelitian ini yang dihilangkan atribut cd 4xl seperti pada tabel 5. Setelah itu dataset diubah menjadi data tabular seperti pada tabel 5. Fp-tree dibuat dari pola pattern yang ditunjukkan pada tabel 6. Berikut merupakan $f p$ tree yang telah dibuat dari pola diatas seperti yang ditunjukan pada gambar 2. Langkah selanjutnya adalah melakukan atau diterapkannya algoritma FP-Growth untuk mencari frequent itemset yang signifikan. Tahap pertama adalah pembangkitan conditional pattern base. Hasil dari tahap pembangkitan conditional pattern base yang ditunjukan pada tabel 6 .

Pada tabel 6 merupakan hasil pembangkitan conditional pattern base dimana condition pattern base itu dilihat dari jalannya lintasan pada $f p$-tree yang dilihat dari nilai support terkecil. Tahap selanjutnya adalah tahap pembangkitan conditional fp-tree. Berikut merupakan hasil dari tahap pembangkitan conditional FP-Tree yang ditunjukan pada tabel 7. Pada tabel 7 merupakan hasil dari conditional fp-tree dimana item yang memiliki support count diatas batas minium yaitu dua maka akan diguakan sedangkan item yang memiliki support count satu tidak 
digunakan. Tahap selanjutnya adalah tahap pencarian frequent itemset. Berikut merupakan hasil tahap pencarian frequent itemset yang ditunjukkan pada tabel 8.

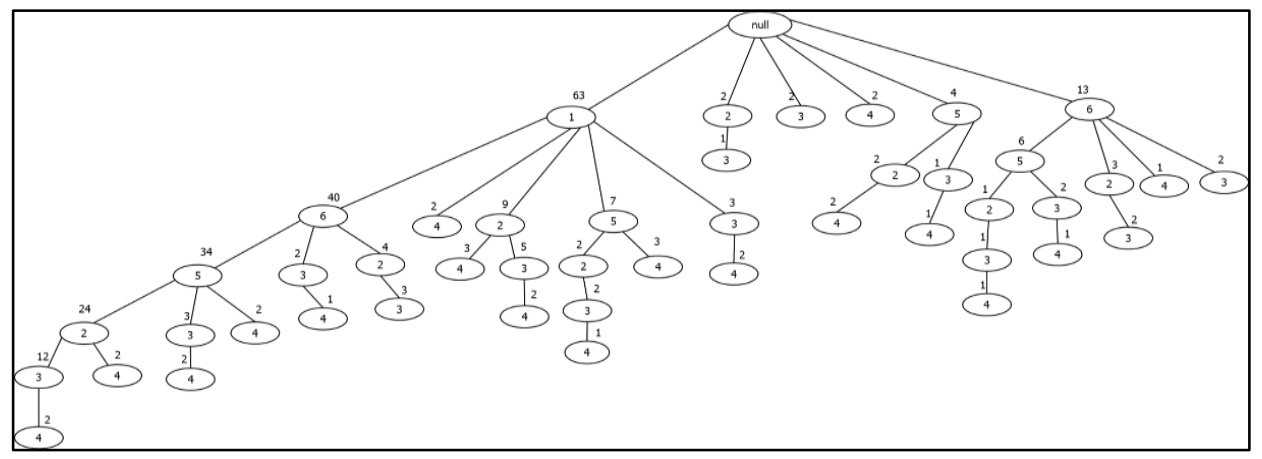

Gambar 2. FP-Tree

Keterangan:

$1=\mathrm{cd}$

$2=\mathrm{cd} x \mathrm{xl}$

$3=$ cd jupe

$4=$ cd jupe $\mathrm{xxl}$
$5=$ short

$6=$ short $\mathrm{xxl}$

Tabel 6. Conditional Pattern Base

\begin{tabular}{cc}
\hline Item & Conditional Pattern Base \\
\hline & $\{1,6,5,2,3: 2\},\{1,6,5,2: 2\},\{1,6,5,3: 2\},\{1,6,5: 2\},\{1,5: 3\}$, \\
Cd Jupe xxl (4) & $\{1,5,2: 1\},\{1: 2\},\{1,2: 3\},\{1,2,3: 2\},\{1,6,3: 1\},\{1,3: 2\},\{5,2: 2\}$, \\
& $\{6,5,2,3: 1\},\{6,5,3: 1\},\{5,3: 1\},\{6: 1\}$ \\
Cd Jupe (3) & $\{1,6,5,2: 12\},\{1,6,5: 3\}\{1,2: 5\},\{1,6,2: 3\}\{1,6: 2\},\{1: 3\}$, \\
Cd xxl (2) & $\{2: 1\},\{6,5,2: 1\},\{6,5: 2\},\{5: 1\},\{6,2: 2\},\{6: 2\}$ \\
Short xxl (6) & $\{1,6,5: 24\},\{1,5: 2\},\{1: 9\},\{1,6: 4\},\{5: 2\},\{6,5: 1\},\{6: 3\}$ \\
Short (5) & $\{1,6: 34\},\{1: 7\},\{6: 6\}$ \\
& $\{1: 40\}$ \\
\hline
\end{tabular}

Tabel 7. Pembangkitan Conditional FP-Tree

\begin{tabular}{cc}
\hline Item & Conditional FP-Tree \\
\hline Cd Jupe xxl (4) & $<1: 22,6: 9,5: 12,2: 10,3: 9>,\langle 5: 5,2: 3,3: 3,6: 3>$ \\
Cd Jupe (3) & $<1: 28,5: 15,6: 20,2: 20\rangle,\langle 5: 4,6: 3\rangle,\langle 6: 4,2: 2\rangle$ \\
Cd xxl (2) & $<1: 39,5: 26,6: 28\rangle,\langle 5: 2\rangle\langle 6: 3\rangle$ \\
Short xxl (6) & $<1: 41,6: 34>,\langle 6: 6>$ \\
Short (5) & $<1: 40>$ \\
\hline
\end{tabular}

Tabel 8. Pencarian Frequent Itemset

Item

Pencarian Frequent Itemset

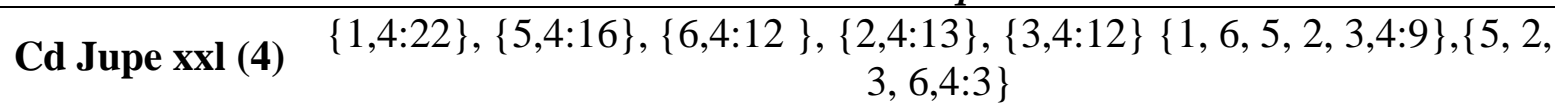

Cd Jupe (3)

$\{1,3: 28\},\{5,3: 19\},\{6,3: 24\},\{2,3: 22\},\{1,6,5,2,3: 15\},\{6,5,3: 3\}$,

Cd xxl (2)

$\{6,2,3: 2\}$

Short xxl (6)

$\{1,2: 39\},\{5,2: 28\},\{6,2: 31\},\{1,6,5,2: 26\}$

Short (5)

$\{1,5: 41\},\{6,5: 40\},\{1,6,5: 34\}$

$\{1,6: 40\}$ 
Pada tabel 8 merupakan frequent itemset yang telah didapat, conditional fp-tree merupakan lintasan tunggal (single path), maka didapatkan frequent itemset dengan melakukan kombinasi item untuk setiap Conditional FP-Tree. Berikut merupakan rekap itemset berdasarkan nilai confidence dan nilai support pada perhitungan manual y yang telah dilakukan seperti pada tabel 9.

Tabel 9. Itemset Perhitungan Manual

\begin{tabular}{ccccc}
\hline No & Premises & Conclution & Support & Confidence \\
\hline $\mathbf{1}$ & Cd XXL (2) & Cd (1) & $45,3 \%$ & $82 \%$ \\
$\mathbf{2}$ & Cd (1), Short (5) & Short XXL (6) & $39,5 \%$ & $82 \%$ \\
$\mathbf{3}$ & Cd (1), Short XXL (6) & Short (5) & $39,5 \%$ & $85 \%$ \\
$\mathbf{4}$ & Short (5), Short XXL (6) & Cd (1) & $39,5 \%$ & $85 \%$ \\
$\mathbf{5}$ & Short (5) & Cd (1) & $47,6 \%$ & $80 \%$ \\
\hline
\end{tabular}

Pada tabel 9 menampilkan itemset yang telah memiliki nilai support diatas batas minimum support $10 \%$ dan nilai confidence diatas minimum confidence $80 \%$. Confidence disini adalah akurasi antara premises dengan conclution dan support disini adalah rata-rata pembelian antara premises dengan conlution Selanjutnya adalah pengolahan data menggunakan tools rapidminer 9.9.000. Untuk pengaturan yang digunakan pada penelitian ini menggunakan minimum support sebesar $10 \%$ atau 0.1 dan minimum confidence $80 \%$ atau 0,8 . Berikut merupakan hasil dari proses data mining menggunakan RapidMiner pada gambar 3.

\begin{tabular}{|c|c|c|c|c|c|c|c|c|}
\hline No. & Premises & Conclusion & Support & Confidence & LaPlace & Gain & p-s & Lift \\
\hline 1 & short & $c d$ & 0.477 & 0.804 & 0.927 & -0.709 & 0.042 & 1.097 \\
\hline 2 & short, cd xxl & cd, short txal & 0.279 & 0.828 & 0.957 & -0.395 & 0.122 & 1.779 \\
\hline 3 & cd, short & short xxl & 0.395 & 0.829 & 0.945 & -0.558 & 0.102 & 1.346 \\
\hline 4 & $\operatorname{cd} x x \mathrm{l}$ & $\mathrm{cd}$ & 0.453 & 0.830 & 0.940 & -0.640 & 0.053 & 1.133 \\
\hline 5 & cd, short xxl & short & 0.395 & 0.850 & 0.952 & -0.535 & 0.120 & 1.433 \\
\hline 6 & short xxl, short & cd & 0.395 & 0.850 & 0.952 & -0.535 & 0.055 & 1.160 \\
\hline 7 & cd, short xxl, cd xxl & short & 0.279 & 0.857 & 0.965 & -0.372 & 0.086 & 1.445 \\
\hline 8 & short, cd xxl & short $x x l$ & 0.291 & 0.862 & 0.965 & -0.384 & 0.083 & 1.399 \\
\hline 9 & short $x \times 1$, cd $x x d$ & cd & 0.326 & 0.875 & 0.966 & -0.419 & 0.053 & 1.194 \\
\hline 10 & short, cd xxl & $\mathrm{cd}$ & 0.302 & 0.897 & 0.974 & -0.372 & 0.055 & 1.224 \\
\hline 11 & $c d$, short, cd xal & short txal & 0.279 & 0.923 & 0.982 & -0.326 & 0.093 & 1.498 \\
\hline 12 & short xxl, short, cd xxl & cd & 0.279 & 0.960 & 0.991 & -0.302 & 0.066 & 1.310 \\
\hline
\end{tabular}

Gambar 3. Hasil RapidMiner

Pada gambar 3 menampilkan hasil yang didapatkan dengan menggunakan aplikasi rapidminer ini adalah berupa pola kombinasi item sebanyak 12 kombinasi dimana dengan memenuhi nilai minimum support sebesar $25 \%$ atau 0,25 dan nilai minimum confidence sebeasar $80 \%$ atau 0,8

\section{Interpretation/Evaluation}

Pada tahap ini dilakukannya mengidentidikasi pola menarik untuk menjelaskan mengenai pengetahuan yang ada. Selanjutnya, dilakukannya proses evaluasi dengan menggunakan Lift ratio dalam pengimplementasiannya. Apabila hasil lift ratio lebih dari satu maka barang yang ada di kolom conclution pasti dibeli bersamaan dengan barang yang ada pada kolom premises. Namun apabila nilai lift ratio dibawah satu maka barang yang ada di kolom conclution tidak dibeli bersamaan dengan barang yang ada pada kolom premises. Berikut merupakan rekap antara nilai support, nilai confidence dan nilai lift dari itemset yang telah didapat seperti pada tabel 10 . 
Berikut merupakan hasil penelitian menggunakan algorima fp-growth yang berupa paket promosi berdasarkan aturan asosiasi yang dihasilkan pada tabel 10. Paket promosi adalah paket promosi 1 berisi cd xxl dan cd, paket promosi 2 berisi cd, short dan short xxl, paket promosi 3 berisi short dan cd.

Tabel 10. Nilai Support, Confidence dan Lift

\begin{tabular}{cccccc}
\hline No & Premises & Conclution & Support & Confidence & lift \\
\hline $\mathbf{1}$ & Cd XXL (2) & Cd (1) & $45,3 \%$ & $82 \%$ & 1,13 \\
$\mathbf{2}$ & Cd (1), Short (5) & Short XXL (6) & $39,5 \%$ & $82 \%$ & 1,34 \\
$\mathbf{3}$ & Cd (1), Short XXL (6) & Short (5) & $39,5 \%$ & $85 \%$ & 1,43 \\
$\mathbf{4}$ & Short (5), Short XXL (6) & Cd (1) & $39,5 \%$ & $85 \%$ & 1,16 \\
$\mathbf{5}$ & Short (5) & Cd (1) & $47,6 \%$ & $80 \%$ & 1,09 \\
\hline
\end{tabular}

\section{Pembahasan}

Pada penelitian ini mengimplementasikan algoritma fp-growth unutk melakukan pencarian pola pembelian konsumen yang sering terjadi yang nantinya akan diproses da menghasilkan itemset untuk dibuat paket promosi dengan menggunakan metode data mining KDD (Knowledge Discovery in Database) yang terdiri dari tahapan data selection, preprocessing, data transformation, data mining dan interpretation/evaluation. Tahap pertama adalah pemilihan data seperti yang sudah dijelaskan sebelumnya. Kemusian dilakukan seleksi data yang menyisakan 302 record data. Selanjutnya adalah transformasi data dengan melakukan pengubahan menjadi data tabular untuk mempermudah proses selanjutnya yaitu proses data mining. Hasil transformasi data bisa dilihat pada tabel 5.

Selanjutnya dilakukan proses data mining. Algoritma yang digunakan adalah fp-growth, dengan menetapkan minimum support sebesar $25 \%$ dan minimum confidence sebesar $80 \%$. Hasil dari data mining bisa dilihat pada tabel 10. Selanjutnya adalah tahap interpretasi/evaluasi dengan mengidentidikasi pola menarik untuk menjelaskan mengenai pengetahuan yang ada. Lalu pola-pola tersebut dilakukannya proses evaluasi dengan menggunakan Lift ratio dalam pengimplementasiannya. Apabila hasil lift ratio lebih dari 1 maka barang yang ada di kolom conclution pasti dibeli bersamaan dengan barang yang ada pada kolom premises. Namun apabila nilai lift ratio kurang dari 1 maka barang yang ada di kolom conclution tidak dibeli bersamaan dengan barang yang ada pada kolom premises. Berikut merupakan perhitungan manual dari lift ratio. Pada tabel 10 menampilkan nilai support, confidence, dan lift dari itemset yang telah didapat, semua nilai yang ada pada tabel talah memenuhi batas minimum. Maka semua aturan yang telah didapat tersebut menunjukkan adanya manfaat dari aturan tersebut karena memiliki nilai lift ratio lebih besar dari satu.

Berdasarkan hal tersebut dapat dikatakan bahwa algoritma fp-growth menghasilkan 5 aturan asosiasi dengan berbagai kombinasi item, yaitu dengan 2 kombinasi item dan 3 kombinasi item. Aturan yang terbuat adalah apabila pelanggan membeli cd xxl maka membeli cd dengan nilai support $42,3 \%$, nilai confidence $82 \%$ dan lift ratio 1.13 . Apabila pelanggan membeli cd dan short maka membeli short xxl dengan nilai support $39.5 \%$, nilai confidence $82 \%$ dan lift ratio 1,34. Apabila pelanggan membeli cd dan short xxl maka membeli short dengan nilai support 39,5\%, nilai confidence $85 \%$ dan lift ratio 1,43. Apabila pelanggan membeli short dan short xxl maka membeli cd dengan nilai support 39,5\%, confidence $85 \%$ dan lift ratio 1,16. Apabila pelanggan membeli short maka membeli cd dengan nilai support $47.6 \%$, nilai confidence $80 \%$ dan lift ratio 1,09 . Hasil penelitian menggunakan algorima $f p$ growth yang berupa paket promosi berdasarkan aturan asosiasi yang dihasilkan pada tabel 10 . Paket promosi adalah paket promosi 1 berisi cd xxl dan cd, paket promosi 2 berisi cd, short dan short xxl, paket promosi 3 berisi short dan cd. 
Sementara itu, pada penelitian sebelumnya yang dilakukan oleh Takdirillah (2020) tentang penerapan data mining dengan menggunakan algoritma apriori sebagai pendukung informasi strategi penjualan yang menghasilkan 3 aturan asosiasi dengan 2 kombinasi item. Hal ini membuktikan adanya perbedaan pada aturan yang dihasilkan bahwa algoritma fp-gowth menghasilkan aturan dengan dengan kombinasi item yang lebih banyak yaitu 3 kombinasi item.

\section{SIMPULAN}

Berdasarkan hasil penelitian yang telah dilakukan dapat diambil kesimpulan yaitu telah didapatkan aturan-aturan yang diketahui dengan menggunakan algoritma fp-growth, dimana aturan asosiasi ini dapat membuat strategi untuk meningkatkan penjulan pakaian. Dari hasil penerapan data mining terhadap data transaksi lalu diproses dengan menggunakan algoritma fp-growth dihasilkan 5 aturan asosiasi yang siap dijadikan untuk pembuatan paket promosi pakaian dengan memenuhi nilai support dan nilai confidence yang telah ditetapkan diawal.

\section{REFERENSI}

Abdullah, A. (2018). Rekomendasi Paket Produk Guna Meningkatkan Penjualan Dengan Metode FP-Growth. Khazanah Informatika: Jurnal Ilmu Komputer Dan Informatika, 4(1), 21-26. https://doi.org/10.23917/khif.v4i1.5794

Chandra, A. (2017). Peningkatan Performa Algoritma Apriori Untuk Aturan Asosiasi Data Mining. Semnasteknomedia, 5(1), 85-90.

Fajrin, B., Puspitasari, D., \& Ikawati, D. S. E. (2020). Pengembangan Sistem Rekomendasi Menu Paket Meeting Menggunakan Metode Fp-Growth (Studi Kasus Lotus Garden Hotel Kediri). Jurnal Informatika Polinema, 6(3), 15-22. https://doi.org/10.33795/jip.v6i3.307

Fitria, R., Nengsih, W., \& Qudsi, D. H. (2017). Implementasi Algoritma FP-Growth Dalam Penentuan Pola Hubungan Kecelakaan Lalu Lintas. Jurnal Sistem Informasi, 13(2), 118 124. https://doi.org/10.21609/jsi.v13i2.551

Mardi, Y. (2017). Data Mining: Klasifikasi Menggunakan Algoritma C4.5. Jurnal Edik Informatika, 2(2), 213-219.

Maulana, A., \& Fajrin, A. A. (2018). Penerapan Data Mining Untuk Analisis Pola Pembelian Konsumen Dengan Algoritma Fp-Growth Pada Data Transaksi Penjualan Spare Part Motor. Klik - Kumpulan Jurnal Ilmu Komputer, 5(1), 27-36. https://doi.org/10.20527/klik.v5i1.100

Maulidiya, H., \& Jananto, A. (2020). Asosiasi Data Mining Menggunakan Algoritma Apriori Dan Fp-GROWTH sebagai Dasar Pertimbangan Penentuan Paket Sembako. Proceeding SENDIU 2020, 36-42. Semarang: UNISBANK.

Pamulang, M. N. P., Aini, M. N., \& Enri, U. (2021). Komparasi Distance Measure Pada KMedoids Clustering untuk Pengelompokkan Penyakit Ispa. Edumatic : Jurnal Pendidikan Informatika: Jurnal Pendidikan Informatika, 5(1), 99-107. https://doi.org/10.29408/edumatic.v5i1.3359

Prahartiwi, L. I. (2017). Pencarian Frequent Itemset pada Analisis Keranjang Belanja Menggunakan Algoritma FP-Growth. INFORMATION SYSTEM FOR EDUCATORS AND PROFESSIONALS, 2(1), 1-10.

Pranata, B. S., \& Utomo, D. P. (2020). Penerapan Data Mining Algoritma FP-Growth Untuk Persediaan Sparepart Pada Bengkel Motor (Study Kasus Bengkel Sinar Service). Bulletin of Information Technology (BIT), 1(2), 83-91.

Rahmat C.T.I., B., Agidtama Gafar, A., Fajriani, N., Ramdani, U., Rihin Uyun, F., Purnamasari P., Y., \& Ransi, N. (2017). Implemetasi k-means clustering pada rapidminer untuk analisis daerah rawan kecelakaan. Seminar Nasional Riset Kuantitatif Terapan, 58-60. Kendari: Universitas Halu Oleo.

Sari, V. R., Firdausi, F., \& Azhar, Y. (2020). Perbandingan Prediksi Kualitas Kopi Arabika 
dengan Menggunakan Algoritma SGD, Random Forest dan Naive Bayes. Edumatic: Jurnal Pendidikan Informatika, 4(2), 1-9. https://doi.org/10.29408/edumatic.v4i2.2202

Setiawan, A., \& Anugrah, I. G. (2019). enentuan Pola Pembelian Konsumen pada Indomaret GKB Gresik dengan Metode FP-Growth. Jurnal Nasional Komputasi Dan Teknologi Informasi (JNKTI), 2(2), 115-125. https://doi.org/10.32672/jnkti.v2i2.1564

Syahra, Y. (2019). Implementasi Data Mining Untuk Penjualan Paket Promosi Pada I-Mobil Dengan Menggunakan Algoritma Frequent Pattern Growth Pada PT. Indomarco Prismatama. Jurnal Teknologi Sistem Informasi Dan Sistem Komputer TGD, 2(1), 42-53.

Takdirillah, R. (2020). Penerapan Data Mining Menggunakan Algoritma Apriori Terhadap Data Transaksi Sebagai Pendukung Informasi Strategi Penjualan. Edumatic: Jurnal Pendidikan Informatika, 4(1), 37-46. https://doi.org/10.29408/edumatic.v4i1.2081

Uska, M., Wirasasmita, R., Usuluddin, U., \& Arianti, B. (2020). Evaluation of RapidminerAplication in Data Mining Learning using PeRSIVA Model. Edumatic: Jurnal Pendidikan Informatika, 4(2), 164-171. https://doi.org/10.29408/edumatic.v4i2.2688 